\title{
Use of Structural Equation Modeling to Empirically Study the Turnover Intentions of Information Technology Professionals in Pune City
}

\author{
R. Raman ${ }^{1 *}$, S. Vijayakumar Bharathi', V. Sesha² and Shaji Joseph ${ }^{1}$ \\ 'Symbiosis International University, Symbiosis Centre for Information Technology, Pune, Maharashtra, \\ India; director@scit.edu, svkbharathi@scit.edu, shaji@scit.edu \\ 2Freelance Management Consultant, Chennai, Tamil Nadu, India; seshaallen@gmail.com
}

\begin{abstract}
Organizations are still finding strategies to retain good workforce, and understand the turnover intentions of employees. Software companies in India are providing good salary packages, excellent performance based bonus and incentives, but all this does not prevent employees from quitting. This paper provides an indepth understanding on the effect of various factors like work-family life conflict, work stress, role ambiguity, job satisfaction and organizational commitment, on the turnover intentions of an IT employee. This study was carried out in Pune, Maharashtra. The study revealed the clarity of role and adequacy of resources, nurturing employee loyalty, organizational inspiration as the key drivers against turnover intentions. Interestingly, the study found that work-family-conflict and work stress did not lead to turnover intentions.
\end{abstract}

Keywords: Organizational Commitment, Job Satisfaction, Turnover Intentions, Work-Family Conflict, Work Stress, Role Ambiguity, Information Technology.

\section{Introduction}

Indian Software organizations are taking measures to ensure that employees are satisfied and do not get intentions to quit. These measures include innovative direct and indirect benefits like excellent compensation, performance based incentives, annual bonus and increments, medical travel assistance, extended health care to family members, employee stock options, flexible work timing, compulsory leave every year, attractive work environment etc. They are also providing cutting edge training and state of the art technical skills to their employees to keep pace with the current trends. Findings $[1,2]$ indicate that high performers are motivated by specific challenging goals and feedback. This aspect has also been addressed by many Indian software blue chip companies. In spite of this, the issue of retaining good workforce is one of the primary concerns of software companies, and many of them are struggling to acquire and retain good quality work force. This fact is also acknowledged by The National Association of Software and Services Companies (NASSCOM), and they term it as a work force crisis. The study of Information Technology (IT) professionals as a separate occupational group has been motivated by the need to further understand IT workers [3]. An extensive review of the literature on IT professionals revealed that majority of research on turnover issues has been undertaken in the western world. Very little research work has been done on this issue in the developing world in general.

Turnover of employees has been an important challenge for organizations ever since management recognized the advantage of retaining its motivated, skilled and

*Corresponding author:

R. Raman (director@scit.edu) 
productive workforce which is vital for organizational performance and competitiveness. Turnover of the employees is not only expensive [4] but also reduces organizational effectiveness and employee morale [5]. Turnover also leads to loss of tacit knowledge and skills [6]. Several studies have been carried out to understand Job satisfaction and Commitment among IT employees and its relation to turnover intentions [7]. From the various studies listed above, we found that there were three factors that can positively impact turnover intentions namely work family conflict, work stress, role ambiguity and two factors that can negatively impact turnover intentions namely Job satisfaction, and Organizational Commitment (OC). Though there are several other factors relating to turnover intentions like social norms, job identification, job description, performance appraisals and succession planning, we found that all these factors were capable of being tested within the five factors identified above. For instance, job identification factors leading to turnover intentions are covered under role ambiguity and work stress. Social norms were tested through work family conflict. The related research, which works on the five constructs are given in the subsequent paragraphs.

Turnover is regarded as an individual's estimated probability that they will stay in an employing organization [8]. Turnover is both voluntary and non-voluntary and it is the voluntary turnover that is the focus of this study [9]. Several studies have been carried out to identify the variables associated with turnover intentions [10, 11]. Turnover Intention (TI) is defined as an employee's decision to leave an organization voluntarily $[12,13]$. It has been identified as the immediate precursor for turnover behavior [14]. Moore \& Burke [15] stressed that job and organizational factors have an impact on the turnover culture found in the IT workforce. Various factors contributing to turnover intentions have been studied [16-18] over the years, It is also a fact that job satisfaction and organizational commitment play important roles in affecting turnover intention $[19,20]$. Mathieu \& Zajac [21] found that intent to leave or stay is strongly and consistently related to voluntary turnover $[22,16]$. Empirical studies have reported that turnover intention can reduce the overall effectiveness of an organization [23].

\subsection{Work Family Conflict (WFC)}

Although many industrial and organizational psychologists, management scientists and sociologists have been interested in turnover intention, in many research on role stress WFC was being neglected at work and family were often viewed as separate mutually exclusive life domains. After the seminal research work carried out [24] on organization role theory, many research works have looked into the relationship between work role stress and its consequences on JC, on OC and even on employee turnover. Greenhaus \& Beutell [25] identified the three major forms of WFC: time-based, strain-based and behaviorbased work-family conflict. It was found $[26,27]$ that the interface of work and family produces stress and strains for employees. Later studies [28] gave an insight that IT professionals have very limited and fixed amounts of time and energy to spend with the family which creates work family conflict. Foley et al. [29] gave several conclusions like work role stresses can lead to increase in levels of work family conflict; it can be a source of occupational stress among IT professionals. Two new concepts were brought about [30] Work-family conflict and Family work-conflict. Work-family conflict was defined as the interference of work with family life and Family work-conflict as the interference of family with work. Frone [31] in his research used a broader concept in regard to work-family balance. This concept contains both the negative and the positive side of work-family balance. Foley et al. [29] pointed out that work-family conflict can instigate in either field such that family can interfere with work duties or work can interfere with family needs. Ahuja et al. [32] using Moor's [33] framework developed a study on the IT professionals from India and found that perceived work overload, autonomy, fairness, and work exhaustion as some of the factors causing the work family conflict and also found that work-family conflict will negatively influence organizational commitment among IT road warriors.

\subsection{Work Stress}

It has been found to be a crucial factor affecting the performance and tenure of IT professionals, given the unique nature of the IT profession. Stress is described as an employee's affective reaction to elements of the workplace and work environment. Chan et al. [34] has defined stress as a response to the perceived relationship between the demands of individuals and their ability to adjust to their work environment. Carayon et al. [35] found that stress arises when the person interacts with the work environment that threatens the individual's physical, psychological and physiological homeostasis. IT work has been characterized by tight deadlines, 
huge workload, extensive projects, rapid and continuous technological change, rapid obsolescence of technical skills, hence continuous updating of new technical skills and long work hours [36]. Stress and work exhaustion play an important role in increasing turnover of employees, a heavier workload leading to burnout and exhaustion [33]. There is a positive relationship between job stress and turnover intentions. Increased workload, increases stress and fatigue [37]. Smith \& Bourke [38] also identified a significant and positive relationship between workload and perceived work-related stress. Ahuja et al. [32] found that the perceived workload affects work exhaustion, and work exhaustion affects turnover intention. The most important factor associated with stress in IT professionals was the pressure to meet specific deadlines [39] causing the time pressure to magnify the work overload problem. Work exhaustion has a direct effect on IT employee turnover intentions and an indirect effect through its influence on job satisfaction [40].

\subsection{Role Ambiguity}

Arises when individuals do not have clear authority or knowledge about how to perform the assigned jobs [41, 42]. It occurs due to lack of clarity of one's duties, plans, goals and uncertainty about the amount of authority granted to perform tasks [41]. Kahn et al. [24] classify role ambiguity as "a direct function of the discrepancy between the information available to the person and that which is required for adequate performance of his [or her] role" as per the role stress theory [24], role ambiguity leads to decreased job satisfaction $[43,44]$ and hence exert negative indirect effects on the intention to quit one's job. Ambiguity in the role played makes role as a source of stress, having direct influence on job-related stress and turnover intention. Dunham have reported [45] that role ambiguity is negatively related to affective and normative commitments. Ambiguity in the role played decreases employee identification with organizational values and the psychological attachment to the organization (affective commitment), as well as their moral obligation to the organization (normative commitment) [46]. A 2012 study of nurses [47] brings out very important aspects of role ambiguity in employee satisfaction.

\subsection{Job Satisfaction}

Job Satisfaction (JS) is an attitude that individuals have about their jobs. It results from their perception of their jobs [42]. The concept of job satisfaction was originally proposed by Hoppock [48]. He defined job satisfaction in his book as: employee' feeling about the environment both in psychological and physical and the employee's subjective reaction to the working situation, including the overall satisfaction of individual psychology, physical environment and working environment [49]. JS is generally defined as "a pleasurable or positive emotional state resulting from the appraisal of one's job or job experiences" [50]. Greenberg \& Baron [51] define job satisfaction as an individual's cognitive, affective, and evaluative reactions towards his or her job. It is found that an increase in the level of turnover intention is produced by a decrease in the level of job satisfaction $[13,52]$. Job Satisfaction was also defined [53, 54] as the extent to which an employee likes his/her current job. Employees dissatisfied with their work are likely to leave the organization as compared to those who think they are treated fairly and duly rewarded. Therefore job satisfaction is negatively associated with turnover [16, 55]. A 2008 study by Lacity et al [56] found a negative relationship between Job Satisfaction and Turnover. Job satisfaction also mediates the relationship between stressful work and intention to leave. An employee who experiences job satisfaction can support stressful work induced by his or her professional environment [57]. JS has a significant and positive relationship with three dimensions of organizational commitment and turnover intention has a significant and negative relationship with job satisfaction and organizational commitment [56]. A 2007 study on Indian BPO by Jyotsna Batnagar identifies that role clarity is one of the major factors for job satisfaction [58].

\subsection{Organizational Commitment}

Can be defined as a bond or linking of the individual to the organization [59]. It is the "strong belief in and acceptance of the organization's goals and values, a willingness to exert considerable effort on behalf of the organization, and a definite desire to maintain organizational membership" [60]. IT employees who are highly committed to their organization are less likely to leave, than those who are relatively uncommitted. The organizational commitment comprises of three distinct dimensions: affective, continuance and normative commitment [61]. Affective commitment is the relative strength of an individual's identification and involvement in a particular organization [60] and an acceptance of its goals and values [62]. Continuance commitment is an attachment based on 
the cost of leaving the organization and Normative commitment is when an employee feels obligated to stay in the organization. Studies [61] reveal employees' commitment to the organization can take various forms and that the antecedents and consequences of each can be quite different. In line with previous IT research $[17,18]$, affective commitment was also found to be negatively related to intentions to "Quit" among IT professionals. Committed IT employees are less likely to leave the organizations than those who are relatively uncommitted. Organizational commitment is a concept that is strongly linked to job satisfaction [63] and both are significantly related to turnover intention [64]. The most widely investigated dimension of organizational commitment was affective commitment. Employee's affective commitment to the organization was the most important component in predicting turnover intentions [65]. Eleven IS studies found a negative relationship between Organizational Commitment and Turnover among IS professionals $[32,66$, $17,9]$, which indicate the importance of an organization's need to focus on fostering organizational commitment, to enhance job satisfaction and reduce job stress.

We chose Pune to carry out this research work, as it is one of the major hubs for IT professionals working in India (Source: NASSCOM). Therefore, it is vital to understand the attitude of IT professionals in Pune and develop a theoretical perspective. It is also important to fill the vacuum in the literature concerning the role of factors like commitment to an organization, job satisfaction, ambiguity in the role played, conflict between work life and the family life and work stress, on the turnover intentions of IT professionals in a non-western context, in particular in Pune-India. This study is divided into four sections: the next section discusses the literature overview. The third section contextualizes the literature review and defines the research hypotheses. The fourth section is on the research methodology and the fifth section discusses the study results and the findings. Finally it is concluded by stating the future scope of work.

\section{Research Hypotheses}

Mowday et. al. [60] states the influence of work-familyconflict on turnover intentions. Turnover intentions have been found to be positively related to work-family conflict [67] hence the hypotheses H1a is given as workfamily conflict will be positively related to turnover intentions. Previous literature suggests that there is a positive relationship between job stress and turnover intentions
[33]. Therefore a hypothesis that can be put forward is hypothesis $\mathrm{H} 2 \mathrm{a}$ as work stress will be positively related to turnover intentions. Role ambiguity leads to decreased job satisfaction [43] and hence exerts negative indirect effects on the intention to quit one's job. Lee [68] found that the effects of role ambiguity, role conflict on IT turnover intention were mediated through job satisfaction. Hence our second hypothesis is proposed as hypothesis $\mathrm{H} 3 \mathrm{a}$, as Role Ambiguity will be positively related to turnover intentions.

Igbaria and Greenhaus [17] found job satisfaction to be a stronger direct antecedent of turnover. Mobley et al. [13] also indicates job satisfaction to be negatively correlated with turnover intentions. Employees experiencing satisfaction with their job are less likely to leave their jobs. High levels of job satisfaction are negatively related to turnover intentions and turnover [16]. We propose our hypotheses $\mathrm{H} 4 \mathrm{a}$, as job satisfaction will be negatively related to turnover intentions.

The review of literature indicates IT employees who are highly committed to their organization are less likely to leave than those who are relatively uncommitted [69]. Past research also indicates a negative relationship between organizational commitment and turnover intentions [59]. Hence we formulate a hypothesis to test the final hypothesis $\mathrm{H} 5 \mathrm{a}$ as organizational commitment will be negatively related to turnover intentions.

Based on the above mentioned hypothesis a theoretical model is presented in Figure 1. This model forms the foundation for analyzing the data, extracting the results for interpretation.

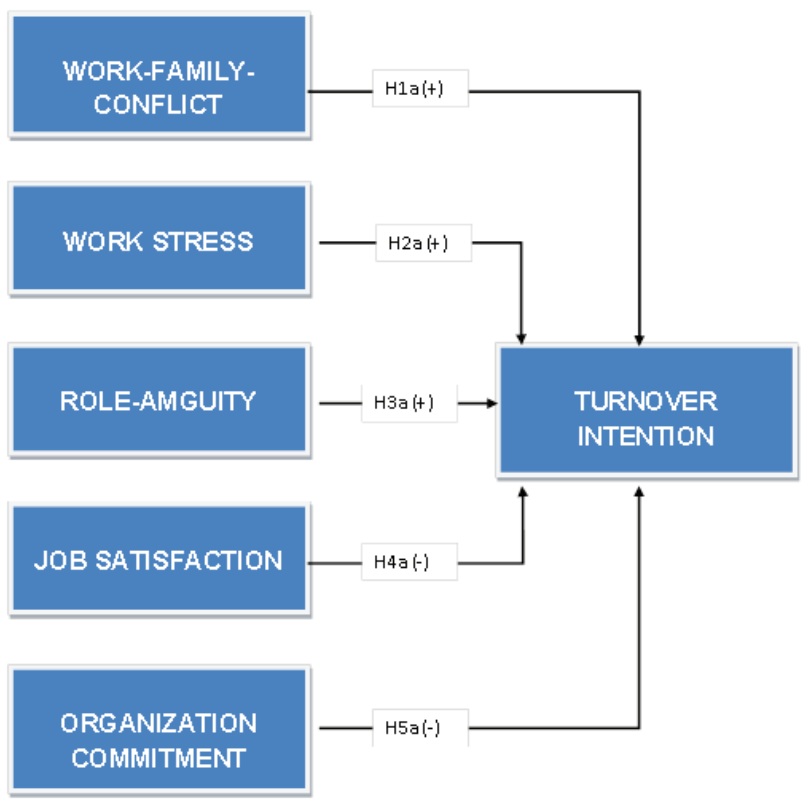

Figure 1. Theoretical model. 
Each of the above constructs is measured by a set of well-defined factors and in all 31 factors was identified. These factors were codified under each construct for further analysis. The codification table (Table 1) is presented.

\section{Research Methodology}

A survey instrument was used to collect data required to test the research hypotheses. To collect data, we approached the Information Technology (IT) companies located at two prime locations in Pune and they extended their support which helped us in conducting the survey. A total of 510 questionnaires was distributed at 10 IT companies, which were multinational corporations having their presence in Pune. The data were collected during November 2011. 98 surveys were excluded due to missing data. A total of 412 usable surveys were finally received, representing a response rate of 80 percent. Dixon et al. [70] stated that response rates of $60 \%$ or above are normally obtained when the study is sponsored by a firm.

Table 1. Construct, variables and codes

\begin{tabular}{|c|c|c|}
\hline Construct & Construct variables & Code \\
\hline \multirow[t]{5}{*}{ Work-Family-Conflict } & My work makes me change my plans for family activities. & WFC1 \\
\hline & The demands of my work interfere with my home and family life. & WFC2 \\
\hline & My job produces strain that makes it difficult to fulfil family duties. & WFC3 \\
\hline & Time spent in my job makes it difficult to fulfil family responsibilities. & WFC4 \\
\hline & Work at home suffers due to the demands my job puts on me. & WFC5 \\
\hline \multirow[t]{3}{*}{ Work Stress } & I receive incompatible requests from more than two higher ups. & WS1 \\
\hline & I do things that are accepted by one person and not accepted by another. & WS2 \\
\hline & I get assignments without adequate resources and materials to execute it. & WS3 \\
\hline \multirow[t]{4}{*}{ Role Ambiguity } & I feel certain about how much control I have on the work assigned to me & RA1 \\
\hline & I have divided my time properly to do various tasks expected of me. & RA2 \\
\hline & I get assignments without the manpower or adequate resources to complete it & RA3 \\
\hline & I believe that there is a "right job-right person" fit in this organization & RA4 \\
\hline \multirow[t]{9}{*}{ Job Satisfaction } & I feel that this organization caters to my aspirations & JS1 \\
\hline & I feel that this organization provides me with opportunity for growth & JS2 \\
\hline & I feel that this organization provides me with an opportunity for self actualization & JS3 \\
\hline & I feel that I have grown along with my organization. & JS4 \\
\hline & I am satisfied with the compensation I receive from my job. & JS7 \\
\hline & My superiors provide enough information about my job performance. & JS8 \\
\hline & I get opportunities to hone my key skills & JS9 \\
\hline & I believe that I get a chance to display my potential skill set & JS10 \\
\hline & I believe that my skills are used for the better development of the company & JS11 \\
\hline \multirow[t]{5}{*}{ Organizational Commitment } & I find that my values and the organization's are very similar. & OC1 \\
\hline & I feel I am loyal to this organization. & OC2 \\
\hline & This organization inspires the best in me in job performance. & OC3 \\
\hline & I would leave this organization with very little change. & OC4 \\
\hline & Deciding to work for this organization was a mistake. & OC5 \\
\hline \multirow[t]{5}{*}{ Turnover Intentions } & I have ideas of quitting my line of work. & TI1 \\
\hline & I often think about quitting my present line of work. & TI2 \\
\hline & I am constantly searching for a better alternative to the present company. & TI3 \\
\hline & I am actively seeking an alternative work role within the present company. & TI4 \\
\hline & I feel to quit the organization due to lack of sense of fulfillment of personal goals. & TI5 \\
\hline
\end{tabular}


The respondents who participated in the survey were carrying out a core IT role or IT support role. The respondents comprised male and female employees, with an average work experience of 4 years and within the age group of 20-30 years only. The questionnaires were distributed and collected with the HR department's support in each company. Each respondent was guaranteed their anonymity, and given a covering letter explaining the purpose of the survey and a postage-paid return envelope. Based on interviews with IT personnel and managers, the constructs were shown to be functionally equivalent (similar function in the target population) and conceptually equivalent (represented by the same attitude and behaviors) $[71,72]$. The survey was designed to collect data from IT personnel to test the hypothesized model. Quantitative research methods were used in this study. This research examined the relationship between inde-pendent and dependent variables. Data were analyzed using SPSS 20 and AMOS and MS Excel spreadsheets. Five-point Likert-type scales ( 1 =strongly disagree, $5=$ strongly agree) was used to record the responses to the items in the questionnaire.

\section{Inference of Results}

One of the primary and crucial measures for evaluating results is the test of data reliability. The internal consistency of the model is measured by reliability. Cronbach alpha was used to test the reliability of measure and it is one of the major criteria for evaluating research instruments. Reliability measures the internal consistency of the model. In this research, Cronbach's alpha has been used to test the reliability of the measures. Higher the value of alpha better is the reliability measure. The reliability acceptance depends on an alpha coefficient of more than 0.7 [73].

The Cronbach alpha coefficient was calculated for the data which comprised of all the six constructs which is shown in Table 2.

From Table 2 it can be inferred that the reliability coefficient for all the constructs except Role Ambiguity are above the acceptable tolerance.

The test of sampling adequacy needs to be performed in order to determine whether the sample is adequately appropriate for factor analysis [74]. Accordingly the Kaiser-Meyer-Olkin (KMO) test of sampling adequacy and Bartlett's test of Sphericity were conducted. The size of the partial correlation amongst the variables considered in each constructed is tested through KMO because small values of correlations amongst the pairs will lack adequate explanation of the other variables in the group and will indicate the inappropriateness of factor analysis. A minimum accepted $\mathrm{KMO}$ value of 0.50 [75] was fixed. The values are presented in Table $2 \mathrm{~A}$.

Based on the values given in Table $2 \mathrm{~A}$ of $\mathrm{KMO}$, the sample adequacy for all the variables that defined the constructs were found to be quite acceptable. The Bartlett's test values for all the construct variables showed that the observed significance level of factors being less than significance value of 0.05 , the initial hypotheses is rejected to conclude that the correlation matrix is not an identity matrix and the relationship among the variables is healthy. If the Bartlett's chi-square value is not significant and positive we advise not to use factor analysis because the variables will not be together loaded properly [76]. The KMO value was found to be comfortably adequate and the chi-square value out of the Bartlett's test was found to be significantly positive for the data contained in all the constructs in our study.

To check the pattern of relationships between the variables, correlation matrix using Pearson Correlation Coefficient was done. We scanned through the correla-

Table 2. Alpha coefficient of constructs

\begin{tabular}{lccl}
\hline Construct & Items & Alpha & Remarks \\
\hline Work Family Conflict & 5 & 0.879 & Good \\
Work Stress & 3 & 0.695 & Acceptable \\
Role Ambiguity & 4 & 0.619 & Questionable \\
Job Satisfaction & 9 & 0.855 & Good \\
Organizational & 5 & 0.749 & Acceptable \\
Commitment & & & \\
Turnover Intention & 5 & 0.842 & Good \\
\hline
\end{tabular}

tion coefficient values and found four variables, two in the Table 2A. KMO and Bartlett's values

\begin{tabular}{lll}
\hline Construct & KMO & Bartlett's \\
\hline Work-Family-Conflict & 0.813 & .000 \\
Work Stress & 0.663 & .000 \\
Role Ambiguity & 0.684 & .000 \\
Job Satisfaction & 0.849 & .000 \\
Organizational Commitment & 0.741 & .000 \\
Turnover Intentions & 0.808 & .000 \\
\hline
\end{tabular}


Job Satisfaction Construct namely "as an employee I find ample amount of time to develop my potential area" (JS5) and "I feel I have the freedom to do what my job demands" (JS6) had a value greater than 0.9 [77]. Similarly one variable each in Organizational Commitment and Turnover Intention namely "I feel that my growth in the company is in sync with the company's growth" (OC6) and "I plan to stay with this organization for at least 3 years" (TI6) respectively had a value greater than 0.9 . Hence these entire four variables were removed from further analysis.

Also the determinant value in each these phases are found to be greater than the necessary value of 0.00001 . Hence there is no significant problem of multi-colinearity or singularity. In other words all these variables correlate fairly well and none of their values are particularly large.

\section{Structural Equation Model Results}

The primary objective of the study is to empirically test the relationship of the six constructs. In other words how do Work-Family-Conflict (WFC), Work Stress (WS), Role Ambiguity (RA), Job Satisfaction (JS) and Organizational Commitment (OC) relate to Turnover Intentions (TI). The structural equation modeling technique was used to test the hypothesized model and the final mode is shown below. For analysis purposes all the five variables that defined the Turnover Intention (TI) construct was combined as one variable. Out of the total 31 variables or factors considered for the survey, only 17 factors were found to be acceptable and eligible for the structural equation model fit. Hence we

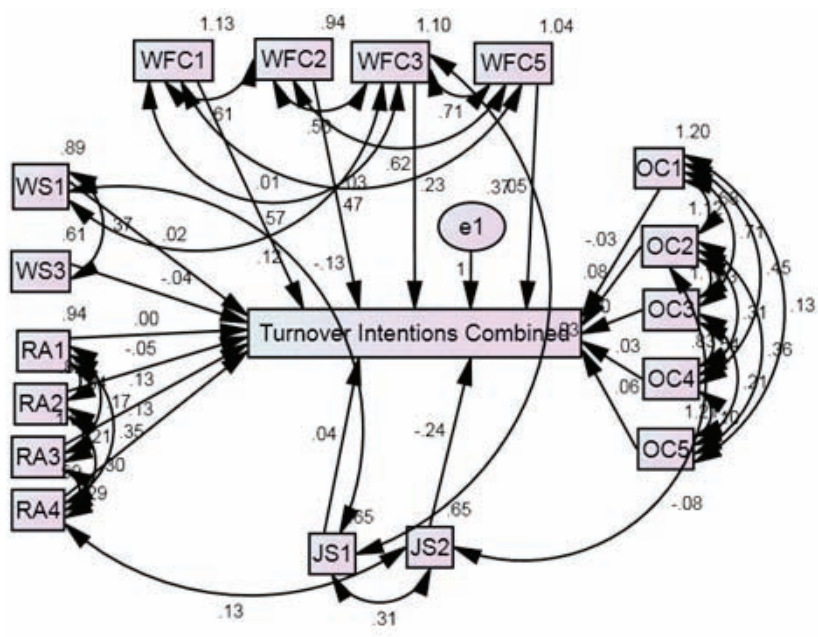

Figure 2. Structural equation model fit. have explained the relevance of these factors only to turnover intentions. The model fit is presented in Figure 2.

Interestingly we found that all the five constructs that were hypothesized for influencing turnover intentions were represented by all or some factors in the model fit. In other words 4 out of 5 factors for the construct WorkFamily-Conflict (WFC) represented in the model fit. With Work Stress (WS) 2 out of 3 factors were represented in the model fit. All the 4 factors of Role Ambiguity (RA) and all the 5 factors of Organizational Commitment (OC) were represented in the model fit. However, only 2 out of the 9 factors that defined Job Satisfaction (JS) were represented in the model fit. Based on these 17 factors we have explained the results of the structural equation model fit in the subsequent paragraphs. The model for construct analysis is given in Figure 3.

From Table 3 it can be found that the calculated values of all the determinants of an acceptable model fit namely CMIN, GFI, AGFI, CFI, TLI, NFI suggested a close fit of the model to the data [85]. The calculated value of RMSEA also indicated a close model fit [84].

\section{Hypothesis Testing Results}

From Table 4, we can understand that there were four construct variables that formed part of the model which contributed to the testing of our first hypothesis (H1a). It can be found that only one variable support the hypothesis

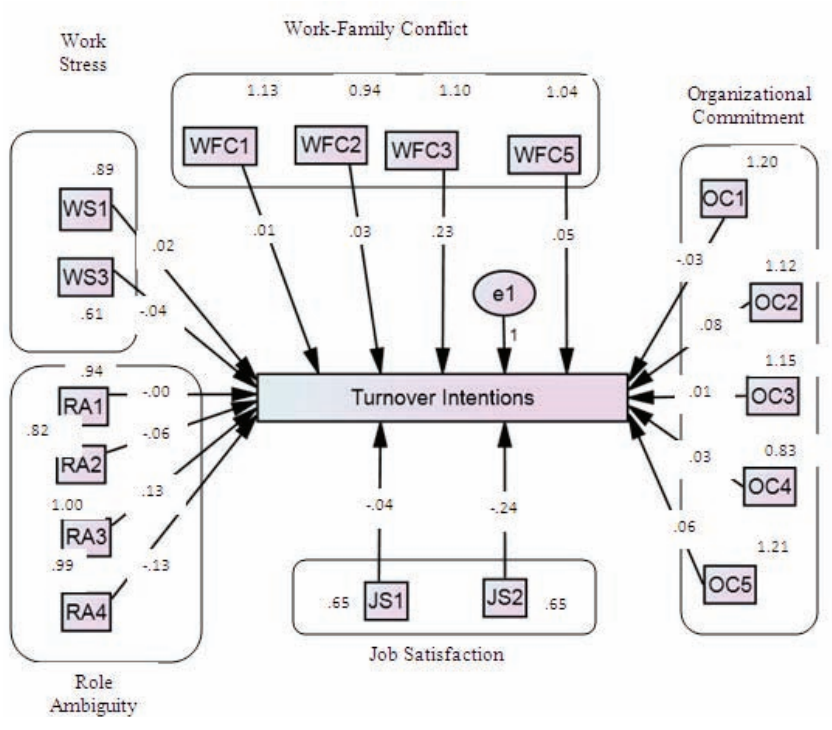

Figure 3. Construct analysis of SEM fit. 
that turnover intentions are positively impacted by WFC issues.

Table 5 comprises of two construct variables that formed part of the model which contributed to the hypothesis ( $\mathrm{H} 2 \mathrm{a})$ testing for the positive relationship between work stress and turnover intentions.

Table 3. Model fit index

\begin{tabular}{lll}
\hline Model Fit Index & Score & \multicolumn{1}{c}{ Standards } \\
\hline $\begin{array}{l}\text { CMIN (Chi-Square/ } \\
\text { Degrees of Freedom) } \\
\chi^{2} / d f\end{array}$ & 1.654 & $\begin{array}{l}\text { 2 to 1 or 3 to 1 [78] } \\
\text { Low as 2 or as high as 5 [79] } \\
\text { A ratio }>2.00 \text { represents an } \\
\text { inadequate fit [80] } \\
>3[81] .\end{array}$ \\
$\begin{array}{l}\text { Goodness of Fit Index } \\
\text { (GFI) }\end{array}$ & 0.954 & $>0.9[82]$ \\
$\begin{array}{l}\text { Adjusted Goodness of } \\
\text { Fit Index (AGFI) }\end{array}$ & 0.927 & $>0.9$ \\
$\begin{array}{l}\text { Comparative Fit } \\
\text { Index (CFI) }\end{array}$ & 0.965 & $>0.9[82]$ \\
$\begin{array}{l}\text { Tucker Lewis Index } \\
\text { (TLI) }\end{array}$ & 0.950 & $>0.9[82]$ \\
$\begin{array}{l}\text { Normed Fix Index } \\
\text { (NFI) }\end{array}$ & 0.918 & $>0.9$ \\
$\begin{array}{l}\text { Root Mean } \\
\text { Square Error of } \\
\text { Approximation } \\
\text { (RMSEA) }\end{array}$ & 0.040 & $<0.050[83,84]$ \\
\hline
\end{tabular}

Table 4. H1a Work-family-conflict will be positively related to turnover intentions

\begin{tabular}{lccc}
\hline Construct variables & $\begin{array}{l}\text { Path } \\
\text { coefficient }\end{array}$ & P & $\begin{array}{l}\text { Alternate } \\
\text { hypothesis }\end{array}$ \\
\hline $\begin{array}{l}\text { My work makes me } \\
\text { change my plans for } \\
\text { family activities (WFC1) }\end{array}$ & .010 & .780 & Not supported \\
$\begin{array}{l}\text { The demands of my } \\
\text { work interfere with my }\end{array}$ & .026 & .556 & Not supported \\
$\begin{array}{l}\text { home and family life } \\
\text { (WFC2) }\end{array}$ & & & \\
$\begin{array}{l}\text { My job produces strain } \\
\text { that makes it difficult } \\
\text { to fulfil family duties } \\
\text { (WFC3) }\end{array}$ & .234 & $* * *$ & Supported \\
$\begin{array}{l}\text { Work at home suffers } \\
\text { due to the demands my } \\
\text { job puts on me (WFC5) }\end{array}$ & & & \\
\hline
\end{tabular}

There were four construct variables that formed part of the model fit. Out of these four variables listed in Table 6, the respondents' perception towards the positive relationship between TI and RA (H3a) was equally divided.

Table 7 shows that out of the two construct variables that tested the hypothesis $\mathrm{H} 4 \mathrm{a}$, the variable which captured the respondents' perception that if an organization can meet the aspirations of its employees it can contribute to reduce turnover intentions was not supported. However, reacting to the fact that opportunities for growth in an organization can negatively contribute to turnover intentions, we found that the respondents' perception was supportive of the hypothesis.

From Table 8, we can find that three variables supported the hypothesis (H5a). The respon-dents felt that their loyalty to the organization can neg-atively contribute

Table 5. H2a WS will be positively related to turnover intentions

\begin{tabular}{lccc}
\hline construct variables & $\begin{array}{l}\text { Path } \\
\text { coefficient }\end{array}$ & P & $\begin{array}{l}\text { Alternate } \\
\text { hypothesis }\end{array}$ \\
\hline $\begin{array}{l}\text { I receive incompatible } \\
\text { requests from more } \\
\text { than two higher ups }\end{array}$ & .020 & .597 & Not supported \\
$\begin{array}{l}\text { (WS1) } \\
\begin{array}{l}\text { I get assignments } \\
\text { without adequate } \\
\text { resources and materials } \\
\text { to execute it (WS3) }\end{array}\end{array}$ & -.037 & .408 & Not supported \\
\hline
\end{tabular}

Table 6. H3a role ambiguity will be positively related to turnover intentions

\begin{tabular}{llll}
\hline Construct Variables & $\begin{array}{l}\text { Path } \\
\text { Coefficient }\end{array}$ & P & $\begin{array}{l}\text { Alternate } \\
\text { Hypothesis }\end{array}$ \\
\hline $\begin{array}{l}\text { I feel certain about how } \\
\text { much control I have on the } \\
\text { work assigned to me (RA1) }\end{array}$ & -.002 & .959 & $\begin{array}{l}\text { Not } \\
\text { supported }\end{array}$ \\
$\begin{array}{l}\text { I have divided my time } \\
\text { properly to do various tasks } \\
\text { expected of me (RA2) }\end{array}$ & -.050 & .176 & $\begin{array}{l}\text { Not } \\
\text { supported }\end{array}$ \\
$\begin{array}{l}\text { I get assignments without } \\
\text { the manpower or adequate } \\
\text { resources to complete it } \\
\text { (RA3) }\end{array}$ & .129 & $* * *$ & Supported \\
$\begin{array}{l}\text { I believe that there is a } \\
\text { "right job-right person" fit } \\
\text { in this organization (RA4) }\end{array}$ & -.126 & $* * *$ & Supported \\
\hline
\end{tabular}


towards quitting. It was found that organization inspires the best in the employees' job performance supported the hypothesis because of the fact that organizational commitment is an outcome of the organizational inspiration that can bring out the best in employee performance and will not contribute towards the quitting intentions. The respondents do not perceive that they have made a wrong decision of joining this company and hence would not quit, which in turn support the hypothesis.

\section{Findings}

The purpose of the study was to identify and explain the factors that contribute turnover intentions of employees in the IT enabled services industry. Based on the analysis of the survey data our findings are explained below.

Table 7. H4a job satisfaction will be negatively related to turnover intentions

\begin{tabular}{lccl}
\hline Construct variables & $\begin{array}{l}\text { Path } \\
\text { coefficient }\end{array}$ & P & $\begin{array}{l}\text { Alternate } \\
\text { hypothesis }\end{array}$ \\
\hline $\begin{array}{l}\text { I feel that this organization } \\
\text { caters to my aspirations }\end{array}$ & .037 & .404 & $\begin{array}{l}\text { Not } \\
\text { supported }\end{array}$ \\
$\begin{array}{l}\text { (JS1) } \\
\begin{array}{l}\text { I feel that this organization } \\
\text { provides me with } \\
\text { opportunity for growth } \\
\text { (JS2) }\end{array}\end{array}$ & -.244 & $* * *$ & Supported \\
\hline
\end{tabular}

Table 8. H5a OC will be negatively related to turnover intentions

\begin{tabular}{lccl}
\hline Construct variables & $\begin{array}{l}\text { Path } \\
\text { coefficient }\end{array}$ & P & $\begin{array}{l}\text { Alternate } \\
\text { hypothesis }\end{array}$ \\
\hline $\begin{array}{l}\text { I find that my values and } \\
\text { the organization's are very } \\
\text { similar (OC1) }\end{array}$ & -.026 & .491 & $\begin{array}{l}\text { Not } \\
\text { supported }\end{array}$ \\
$\begin{array}{l}\text { I feel I am loyal to this } \\
\text { organization (OC2) }\end{array}$ & .078 & .043 & Supported \\
$\begin{array}{l}\text { This organization inspires } \\
\text { the best in me in job } \\
\text { performance (OC3) }\end{array}$ & -.102 & .011 & Supported \\
$\begin{array}{l}\text { I would leave this } \\
\text { organization with very } \\
\text { little change (OC4) }\end{array}$ & .035 & .383 & $\begin{array}{l}\text { Not } \\
\text { supported }\end{array}$ \\
$\begin{array}{l}\text { Deciding to work for this } \\
\text { organization was a mistake } \\
\text { (OC5) }\end{array}$ & .062 & .031 & Supported \\
\hline
\end{tabular}

We found that out of all the variables considered in the five construct namely Work-Family-Conflict (WFC), Work Stress (WS), Role Ambiguity (RA), Job Stress (JS) and Organizational Commitment (OC) on Turnover Intentions (TI) for this research, 17 variables formed part of the structural equation model fit. It was found that 7 variables contributed towards supporting the relevant hypothesis. Only one out of four variables that defined the construct WFC had supported the hypothesis of WFC positively related to turnover intentions. On Work Stress we found that both the variables did not support the hypothesis in other words work stress is not a contributor to turnover intentions. Organizations with a well defined scalar chain along with clarity on the span of control for authority-responsibility relationship can support employee retention. Though all the four variables of Role Ambiguity were fairly highly impactful, only two variables supported the hypothesis that role ambiguity positively relates to turnover intentions. Organizations should also give the adequate degree of empowerment to the employee for the work assigned. Organizations should emphasize and instill the significance of time management to employees in order to adhere to time schedules from a variety of tasks performed by employees in any project. The absence of such practices can lead to role ambiguity and employees will decide on moving out of their organization to escape the ill-effects of role ambiguity. Growth opportunities is what the employees look forward in a satisfying job. It was also found that nurturing employee loyalty; organizational inspiration can delay the retention intention of employees and enhance commitment towards the organization.

\section{Conclusion and Future Scope of Work}

In general, this study has discussed the motives of turnover intention and tested the contributing relationships on turnover intention. The study enables us to understand certain key personal and professional factors that can trigger turnover intentions. Organizations need to enable a healthy working environment in which employees are able to balance their time judiciously for both personal and professional roles. The knowledge sector to which IT industry belongs is working on a time-ismoney model due to which organizational pressures can 
prove very costly to the personal and professional facets of the workforce. Clarity of role and adequacy of resources to complete the given job can reduce role ambiguity and create a feeling of being the right man for the given job. Organization need to also nurture the loyalty of employees and continue to inspire through leadership and culture in bringing out the best from every employee and sustain such efforts by constant recognition and growth avenues. Interestingly work-family-conflict and work stress were not found to be contributing factors to turnover which is in contrary to several global studies. This could be due the sample characteristics like young age, initial stage of career, the need to build a career and excess of workforce supply over demand. The study can also trigger new perspectives of research which can be a cohort, industry and geography specific. The findings may used for comparing the causes of turnover intentions between different industry segments in various geographies so as to devise and practice employees' retention strategies more proactively and effectively.

\section{References}

1. Dowling W (1972). Conversation with David McClelland, Organisational Dynamics, vol 1(1), 56-72.

2. Latham G (2000). Motivat employee performance through goal-setting, In Locke E (Ed), HandBook of Principles of Organisational Behaviour, $2^{\text {nd }}$ Edn., 107-119.

3. Orlikowski W J, and Baroudi J J (2002). Studying information technology in organisations: research approaches and assumptions, Information Systems Research, vol 2(1), 1-28.

4. Eucker T (2007). Understanding the impact of tacit knowledge loss, Management Review, vol 10(1), 10.

5. Kacmar K, Andrews M et al. (2006). Sure every one can be replaced...but at what cost? turnover as a predictor of unitlevel performance, Academy of Management Journal, vol 49(1), 133-144.

6. Liu B, Liu J et al. (2010). Person-organisation fit, job satisfaction, and turnover intention: an empirical study in the chinese public sector, Social Behaviour and Personality: An International Journal, vol 38(5), 615-625.

7. Outlay C N, Pratt R M E et al. (2012). Team and organisational identificaiton among informational systems personnel: an exploratory investigation of post IT outsourcing personnel impacts, 4th Hawaii Interantinonal Conference on System Sciences, 5142-5151.

8. Cotton J, and Tuttle J (1986). Employee turnover: a metaanalysis and review with implications for research, Academy of Management Review, vol 11(1), 55-70.
9. Kamalanabhan S K (2010). A three dimensional analysis of turnover intentions among employees of ITES/BPO sector, South Asian Journal of Management, vol 17(3), 85-103.

10. Maertz C P, and Campion M A (1998). 25 years of voluntary turnover research: a review and critique, Cooper C L \& Robertson I T (Eds.), International Review of Industrial and Organizational Psychology, Wiley, Chichester, England, vol 13(Annual Volume), 49-83.

11. Vikramasinghe V (2010). Imact of time demand of work on job satisfaction and turnover intention: software developers in offshore outsourced software development firms in Srilanka, Strategic Outsourcing: An International Journal, vol 3(3), 246-255.

12. Dogherty T W, Bluedom A C et al. (1985). Precursers of employee turnover: a multiple-sample causal analysis, Journal of Organizational Behaviour, vol 6(4), 257-271.

13. Mobley W H (1977). Intermediate linkages in the relationshsip between job satisfaction and employee turnover, Journal of Applied Psychology, vol 62(2), 237-240.

14. Tett R P, and John P M (1993). Job satisfaction, organiastional commitment, turnover intention and turnover: path analysis based on meta-analytic findings, Personal Psychology, vol 46(2), 259-293.

15. Moore J E, and Burke J E (2002). How to turn around turnover culture in IT, Communications of the ACM, vol 45(2), 73-78.

16. Griffith R W, Hom P W et al. (2000). A meta-analysis of antecedents and correlates of employee turnover: update, moderator tests, and research implications for the next millennium, Journal of Management, vol 26(3), 463-448.

17. Igbaria M, and Greenhaus J H (1992). Determinants of MIS employees' turnover intentions: a structural equation model, Communications of the ACM, vol 26(3), 34-46.

18. Igbaria M, and Guimares T (1999). Exploring differences in employee turnover intentions and its determinants among telecommuters and non-telecommuters, Journal of Management Information System, vol 16(1), 147-164.

19. Steel R P (2002). Turnover theory at the empirical interface: problems of fit and function, Academy of Management Review, vol 27(3), 346-360.

20. Igbaria M, Meredith G et al. (1994). Predictors of intention of IS professionals to stay with the organization in South Africa, Information \& Management, vol 26(5), 245-256.

21. Mathiee J E, and Zajac D M (1990). A review and metaanalysis of the antecedents, correlates, and consequences of organizational commitmen, Psychological Bulletin, vol 108(2), 171-194.

22. Hendrix W H, Robertson T et al. (1999). Effects of procedural and distributive justice on factors predictive of turnover, Journal of Social Behavior and Personality, vol 13(4), 611-632. 
23. Smith M, and Brough P (2003). Personal recruitment and selection, In O’Driscoll M T (Ed.), Organisational Psychology in Australia and New Zealand, 31-35.

24. Kahn R L, Wolfe D M et al. (1964). Organizational stress: studies in role conflict and ambiguity, review by: Harry Levinson, Administrative Science Quarterly, vol 10(1), Special Issue on Professionals in Organizations (Jun., 1965), 125-129. http://www.jstor.org/stable/pdfplus/2391654.pdfa ccept $\mathrm{TC}=$ true\&acceptTC $=$ true\&jpdConfirm $=$ true

25. Greenhaus J H, and Beutell N J (1985). Sources of conflict between work and family roles, Academy of Management Review, vol 10(1), 76-88.

26. Cooper C L, Spector P E et al. (2004). A cross national comparative study of work family stressors, working hours, and well-being: China and Latin America versus the Anglo world, Personal Psychology, vol 57(1), 119-142.

27. Frone M, Russell M et al. (1997). Relation of work-family conflict to health outcomes: a four-year longitudinal study of employed parents, Journal of Occupational and Organizational Psychology, vol 70(4), 325-335.

28. Ruderman M N, Ohlot P J et al. (2002). Benefits of multiple roles for managerial women, Academy of Management Journal, vol 45(2), 369-386.

29. Foley S, Ngo H-Y et al. (2005). The effects of work stressors, perceived organizational support, and gender on work-family conflict in Hong Kong, Asia Pacific Journal of Management, vol 22(3), 237-256.

30. Netmeyer R G, Boles J S et al. (1996). Development and validation of work-family conflict and family-work conflict scales, Journal of Applied Psychology, vol 81(4), 400-410.

31. Frone M R (2003). Work-family balance. Available from psycnet.apa.org

32. Ahuja M K, Chudoba K et al. (2007). IT road warriors: balancing work family conflict, job autonomy, and work overload to mitigate turnover intentions, MIS Quarterly, vol 31(1), 1-17.

33. Moore J E (2000). One road to turnover: an examination of work exhaustion in technology professionals, Management Information Systems Quarterly, vol 24(1), 141-168.

34. Chan K B, Lai G et al. (2000). Work stress among six professional groups: the Singapore experience, Social Science and Medicine, vol 50(10), 1415-1432.

35. Carayon P, Smith M J et al. (1999). Work organization, job stress, and work-related musculoskeletal disorders, Human Factors, vol 41(4), 644-663.

36. Amstrong D J, Reimenschneider C K et al. (2007). Advancement, voluntary turnover and women in IT: a cognitive study of work family conflict, Information and Management Journal, vol 44(2), 142-153.

37. MacDonald W (2003). The impact of job demands and workload on stress and fatigue, Australian Psychologist, vol 38(2), 102-117.
38. Smith M, and Bourke S (1992). Teacher stress: examining a model based on context, workload, and satisfaction, Teaching and Teacher Education, vol 8(1), 31-46.

39. Sethi V, Barrier T et al. (2004). An examination of the correlates of burnout in information system professionals, Information Resources Management Journal, vol 12(3), $5-13$.

40. Kim S E (2007). Is mission attachment an effective management tool for employee retention? an empirical analysis of a nonprofit human services agency, Review of Public Personnel Administration, vol 27(3), 227-248.

41. Rizzo J R, House R J et al. (1970). Role conflict and ambiguity in complex organizations, Administrative Science Quarterly, vol 15(2), 150-163.

42. Ivancevich J M, Matteson M T et al. (1990). Worksite stress management interventions, American Psychologist, vol 45(2), 252-261.

43. Jackson S E, and Schuler R S (1985). A meta-analysis and conceptual critique of research on role ambiguity and role conflict in work settings, Organizational Behavior and Human Decision Processes, vol 36(1), 16-78.

44. Bedeian A G, and Armenakis A A (1981). A path-analytic study of the consequences of role conflict and ambiguity, Academy of Management Journal, vol 24(2), 417-424.

45. Dunham R B, Grube J A et al. (1994). Organizational commitment: the utility of an integrative definition, Journal of Applied Psychology, vol 79(3), 370-380.

46. Iverson R D, and Buttigeig D M (1999). Affective, normative and continuance commitment: can the right kind of commitment be managed?, Journal of Management Studies, vol 36(3), 307-333.

47. Brunetto Y, Farrharton R et al. (2012). Supervisor relationships, teamwork, role ambiguity and discretionary power: nurses in Australia and the United Kingdom, International Journal of Public Administration, vol 35(8), 532-543.

48. Hoppock R (1935). Job Satisfaction, Harper, New York.

49. Zhou Z, and Chunfeng C (2009). Structural empowerment, job satisfaction, and turnover intention of chinese clinical nurses, Nursing \& Health Sciences, vol 11(4), 397-403.

50. Locke E (1976). The nature and causes of job satisfaction, In Dunette M D (Ed.), Handbook of Industrial and Organizational Psychology, Rand McNally, Chicago, 1297-1343.

51. Greenberg J, and Baron R A (1997). Work related attitudes: feelings about jobs, organisation and people, Behavior in Organizations: Understanding and Managing the Human Side of Work, $5^{\text {th }}$ Edn., Chapter 5, Prentice Hall, Upper Saddle River, NJ, Carsten.

52. Porter L, and Steers R (1973). Organisational, work and personal factors in employee turnover and absenteesim, Psychological Bullettin, vol 80(2), 151-176.

53. Carsten J, and Spector P (1987). Unemployement, jobsatisfaction and employee turnover: a meta-analytic test of 
the muchinsky model, Journal of Applied Psychology, vol 72(3), 374-381.

54. Spector E (1996). Feelings about work: job attitudes and emotions, Industrial and Organizational Psychology Research and Practice, Chapter 9, John Wiley and Sons Inc, USA, 222-251.

55. Amah O E (2009). Job satisfaction and turnover intention relationship: the moderating effect of job role centrality and life satisfaction, Research and Practice in Human Resource Management, vol 17(1), 24-35.

56. Lacity C M, Iyer V et al. (2008). Turnover intentions of Indian IS professionals, Information System Front, vol 10(2), 225-241.

57. Paille P, and Grima F (2011). Citizenship and withdrawal in the workplace: relationship between organizational citizenship behaviour, intention to leave current job and intention to leave the organization, The Journal of Social Psychology, vol 15(1), 478-493.

58. Bhatnagar J (2007). Talent management strategy of employee engagement in Indian ITES employees: key to retention, Employee Relations, vol 29(6), 640-663.

59. Meyer J P, Allen N J et al. (1993). Commitment to organisations and occupations extension and test of a three-component conceptualization, Journal of Applied Psychology, vol 78(4), 538-552.

60. Seashore S E (1983). Employee-organization linkages: the psychology of commitment, absenteeism, and turnover, (Review of the book - Employee-organization Linkages: The Psychology of Commitment, Absenteeism, and Turnover by Mowday R T, Porter L W et al.), American Journal of Sociology, vol 88(6), 1315-1317.

61. Meyer J P, and Allen N J (1997). Meaning of commitment, Commitment in the Workplace: Theory, Research and Application, Chapter 2 -Meaning of commitment, Sage, Thousand Oaks, CA, 8-22.

62. Lee-Kelly L, Blackman D A et al. (2007). An exploration of the relationship between learning organizations and the retention of knowledge workers, The Learning Organization, vol 14(3), 204-221.

63. Silverthrone C (2005). Organisational and national culture, Organisational Psychology in Cross Cultural Perspective, Chapter 4 -Organisational and national Culture, NYU Press, New York, 41-56.

64. Aydogdu S, and Asikgil B (2011). An empirical study of the relationship among job satisfaction, organisational commitment and turnover intention, International Review of Management and Marketing, vol 1(3), 43-53.

65. Foon Y, Leong L et al. (2010). An exploratory on turnover intention among private sector employees, International Journal of Business and Management, vol 5(8), 57-64.

66. Baroudi J J (1985). The impact of role variables on information systems personnel work attitudes and intentions, MIS Quarterly, vol 9(4), 341-356.
67. Grandey A A, and Cropenzano R (1999). The conservation of resources model applied to work-family conflict and strain, Journal of Vocational Behaviour, vol 54(2), 350-370.

68. Lee K, Carswell J et al. (2000). A meta-analytic review of occupational commitment: relation with person-and work related variables, Journal of Applied Psychology, vol 85(5), 799-811.

69. Mathis R L, and Jackson J H (2004). Talent management, Human Resource Management, Chapter 9 -Talent Management, Thompson South Western, Australia, 290-323.

70. Dixon A L, Susan M et al. (2003). Attributions and behavioural ntentions of inexperienced sales persons to failure: an empirical investigation, Journal of the Academy of Marketing Science, vol 31(4), 459-467.

71. Kumar V (2000). Multivariate analysis, International Marketing Research, Chapter 15 -Multivariate Aanalysis, Prentice-Hall Inc, Upper Saddle River NJ.

72. Singh J (1995). Measurement issues in cross-national research, Journal of International Business Studies, vol 26(3), 597-619.

73. George D, and Mallery P (2003). Reliability test, SPSS for Windows step by step: A Simple Guide and Reference, $4^{\text {th }}$ Edn., Chapter 18, Allyn \& Bacon, Boston, 52-56.

74. Anderson T M, and Herbertson T T (2003). Measuring Globalization, IZA Discussion Paper (817) Available from: http://ssrn.com/abstract $=434540$

75. Kaiser F G (1974). An index of factoral simplicity, Psychometrika, vol 39(1), 31-36.

76. Marjorie P A, Lackey N R et al. (2003). An overview of factor analysis, Making Sense of Factor Analysis: the use of Factor Analysis for Instrument Development in Health Care Research, Chapter 5, Sage Publication, Inc, Thousand Oaks, CA, 131-164.

77. Field A (2005). Discovering Statistics using SPSS for Windows: Advanced Techniques for Beginners, Introducing Statistical Methods Series, $2^{\text {nd }}$ Edition, Chapter 15, Sage, 619-675.

78. Carmines G, McIver E G et al. (1981). Analyzing models with unobserved variables: analysis of covariance structures, In Bonstedt W G, and Borgatta F E (Eds), Social Measurement: Current Issues, 65-115.

79. Marsh H W, and Hocewar D (1985). Application of confirmatory factor analysis to the study of self concept: first and higher order factor models and their invariance across groups, Psychology Bulletin, vol 97(3), 562-582.

80. Byrne B M (1994). Application 6, Structural Equation Modeling with EQS and EQS/Window: Basic concepts, applications and programming, Chapter 8, Sage, $159-176$.

81. Straub D W (1989). Validating instruments in MIS research, MIS Quarterly, vol 13(2), 147-169. 
Use of Structural Equation Modeling to Empirically Study the Turnover Intentions of Information Technology Professionals in Pune City

82. Bentler P M, and Bonnet D G (1980). Significance tests and goodness of fit in the analysis of convenience structure, Psychological Bulletin, vol 88(3), 588-606.

83. Marsh H W, Hau K T et al. (1988). Is more ever too much? the number of indicatiors per factor in confirmatiory factor analysis, Multivativariate Behavioural Research, vol 33(2), 181-220.
84. Browne M, and Cudeck R (1993). Alternative ways of assessing model fit, In Bollen K A, and Long J S (Eds), Testing Structural Equation Models, 136-162.

85. Bentler P (1990). Comparative fit indexes in structural models, Psychological Bulletin, vol 107(2), 238-246. 